\title{
Coffee Thread Blight (Corticium koleroga): a Coming Threat for Ethiopian Coffee Production
}

\author{
Kifle Belachew*, Demelash Teferi and Legese Hagos
}

Ethiopian Institute of Agricultural Research, Jimma Agricultural Research Centre, Plant Pathology Research Section, P.O. Box 192, Jimma, Ethiopia.

\begin{abstract}
Besides its importance coffee production constraints with number biotic factors of which diseases are major. Coffee is prone to a number of diseases that attack fruits, leaves, stems and roots, and reduce yield and marketability. Major coffee diseases in Ethiopia are Coffee berry diseases (Colletotrichum kahawae), Coffee wilt disease (Gibberella xylarioides) and coffee leaf rust (Himalia vestatrix) however, the rest diseases considered minor. Thread blight of coffee caused by Corticium koleroga is an important disease of Coffee in India. Thread blight diseases in Ethiopian coffee for first time recorded at Gera and Metu agricultural research sub-stations in 1978. However it sporadically occurs between June and September, but becoming important at high land coffee growing areas of southwestern, Ethiopia. Investigations including diagnostic surveys for assessing the disease occurrence, prevalence, incidence and severity was conducted and the sample was brought to Plant Pathology Laboratory of Jimma Agricultural Research Center. The results of study showed that the disease syndrome on detached coffee plants were similar with thread blight of coffee recorded so far and observed at the field. The disease invariably attacks coffee leaves, branches, twigs and berries with characteristic blight symptoms. White fungal threads were seen on the young stems and succulents tender tissues of coffee trees. These threads eventually become dark brown in color grow and spread to cover underside of leaves while coffee berries on infected braches are also completely destroyed leading to total crop failure. The isolation and identification of the causal pathogen from samples of leaves, berries, branches and shoots consistently produced fungal species which may be Corticium koleroga that further proved by pathogenicity tests. The disease mean incidence and severity during first outbreak (2008) at Limmu coffee plantation farm of "Gummer" was 49.02 and $9.8 \%$, respectively. The second reported outbreak of the diseases was from Bebeka coffee estate of "Disadis" farm (2012). Current area wide outbreak at major coffee growing areas of southwest, west and south Ethiopia was in 2014 with mean incidence and severity of 58.44 and $32.59 \%$, respectively, resulting in considerable damages. Among others, climatic factors prolonged rainfall with long period of wet favored the thread blight disease outbreaks implicating the present climate change scenarios are favoring challenging diseases on Arabica coffee production in Ethiopia.
\end{abstract}

Keywords: Black rot of coffee; Ceratobasidium noxium; Corticium koleroga; Pellicularia koleroga; Thread blight

\section{Introduction}

Coffee is not only one of the highly preferred international beverages, but also one of the most important trade commodities in the world next to petroleum [1]. It is currently grown over eighty countries in the tropical regions with an estimated 125 million people in Latin America, Africa and Asia depend on it for their livelihoods [2,3]. Global annual production in 2011 accounted to about 7.86 million tonnes of green beans [1]. Despite the largest percentage reduction in coffee production among 10 leading producers, Ethiopia remains the fifth leading coffee producer in the world and first from Africa. Ethiopia's coffee consumption also is 9th in the world ahead of UK and Inidia [4].

Coffee is prone to a number of diseases that attack fruits, leaves, stems and roots, which in turn reduce yield and marketability $[5,6]$. High rainfall and relative humidity are common in major coffee growing areas, which favors disease development and survival of inoculums on crop or alternate hosts over seasons. These conditions generally result in disease epidemics that reduce coffee yield. Very more than 13 types of diseases registered to affect coffee plant in Ethiopia. While major coffee diseases are Coffee Berry Diseases (CBD) caused by Colletotrichum kahawae, Coffee Wilt Disease (CWD) of Gibberella xylarioides and coffee leaf rust caused by Hemileia vastatrix, however the rest of diseases considered to be minor $[5,6]$.

Thread blight of coffee caused by the phytopathogenic fugi (Corticium koleroga) is an important disease of Coffee in India,
Trindad and Tobego. The disease is fungal which attacks coffee berries and all plant parts except root. The disease associated with fungal pathogens from the Ceratobasidium species complex is considered an emerging one and has a very wide hosts ranging from annual herbaceous monocots to perennial woody fruit trees with many kinds of symptoms, which is extremely difficult to control and result in significant economic losses [7].

The first description of the white-thread blight and black rot pathogen was reported on coffee by Cooke in 1876 in India [8,9]. Cooke considered the pathogen a hyphomycete and named it Pellicularia koleroga. In 1910, Von Hoehnel re-described the pathogen naming the fungus as Corticium koleroga (Cooke) von Höhnel 1910 [8]. In addition to Corticium koleroga, synonymy of $P$. koleroga has included Botryobasidium koleroga (Cooke) Venkatarayan, Hyphocnus koleroga

${ }^{*}$ Corresponding author: Kifle Belachew, Ethiopian Institute of Agricultural Research, Jimma Agricultural Research Centre, Plant Pathology Research Section, P.O. Box 192, Jimma, Ethiopia, Tel: +251911067034; E-mail: kiflekef@gmail.com

Received September 16, 2015; Accepted September 25, 2015; Published September 28, 2015

Citation: Belachew K, Teferi D, Hagos L (2015) Coffee Thread Blight (Corticium koleroga): a Coming Threat for Ethiopian Coffee Production. J Plant Pathol Microb 6: 303. doi:10.4172/2157-7471.1000303

Copyright: (c) 2015 Belachew K, et al. This is an open-access article distributed under the terms of the Creative Commons Attribution License, which permits unrestricted use, distribution, and reproduction in any medium, provided the original author and source are credited. 
Stevens \& Hall, Koleroga noxia Donk and Ceratobasidium noxium (Donk) P. Roberts [10,11]

Thread blight diseases on Ethiopian coffee was observed for first time at Gera and Metu agricultural research sub-stations in 1978 and it might have been existed before [5,12]. However, this disease sporadically occurs between June and September, but increasingly becoming important at Gera, Metu and Limmu coffee plantation "Gumer". Currently, climate change not only favors the proliferation of certain diseases and pests, but also results in the spreading to regions where they were not existed. Thread blight of coffee outbreak was observed in different coffee plantations like at Limmu in 2008, at Bebeka in 2012 and at Limu horizon in 2014. Currently thread blight disease become significantly important disease in coffee growing areas of Ethiopia. Therefore, investigation including diagnostic survey on disease severity and incidence accompanied by infected coffee specimen's collections were conducted along with isolation and identification of the causal pathogen.

\section{Materials and Methods}

\section{Survey areas}

Survey was conducted during 2013/2014 cropping season at major plantation coffee farms of southwest and south Ethiopia to determine the distribution, incidence and severity of coffee thread blight. Surveyed farms are Agricaft of "Duwina" coffee plantation in Sheka zone of Southern Nations and Nationalities Peoples Region (SNNPR) and Limmu coffee plantation of Horizen PLC which is found in Jimma zone of Oromia Regional State. Additionally, coffee farms at Gera agricultural research sub center in southwestern Ethiopia and Awada agricultural research sub center in southern Ethiopia were observed. From each plantation five representative blocks and from each center different coffee trail plots were used for diseases assessment.

\section{Disease assessment}

Coffee diseases assessment was done to know the current occurrence and distribution of outbreak of thread blight diseases in the above mentioned areas (section 2.1). A clustered sampling procedure was used, where five coffee blocks were sampled at each farm. At existing coffee blocks, the assessment was readily undertaken following each row per sample plot in an ordinary manner for disease incidence and severity across the block. At the spot number of diseased and healthy coffee trees in each sample field was counted and recorded. Besides secondary information on coffee varieties, planting years (estimated age), agronomic practices (slashing, hoeing, pruning, shed and or open etc), field history (related to disease outbreak) and other relevant data were gathered during the survey.

In order to identify possible climatic and metrological data's that influence the occurrence and distribution of diseases outbreak, additional biophysical data, i.e., mean rainfall, temperature and relative humidity were collected from nearest metrological stations in each sample area.

Sampled trees were physically numbered from 1-30. Three pairs of branches each pair from upper, middle and lower canopy layers of the coffee plant, was selected and marked with label to assess diseases incidence and severity at each area.

\section{Incidence}

For each assessed farm blocks, disease incidence was determined by counting the number of diseased trees over total observed trees.
Disease incidence was obtained by the following formula.

Disease incidence $(I)=\frac{\text { number of infected trees or leaves or berries }}{\text { Total number of assessed trees or leaves or berries }} \times 100$

\section{Severity}

Disease severity on trees, leaves or berries was estimate based on percent area covered by lesions of the disease over total area observed.

$$
\text { Disease severity }(s)=\frac{\text { plant part covered by lesions or rot }}{\text { Total plant part assessed }} \times 100
$$

\section{Isolation and Identification of diseases causing pathogen}

Diseased twigs, leaves and berries were sampled from each farm. Which shows clear thread blight symptom was identified and semi infected leaves, branches and berries were collected and packed in perforated plastic bag. All samples were properly labeled with location (region, zone, district, localities, farm and altitude) cultural practices conducted and collection date, and then isolation was done at Jimma Agricultural Research Center plant pathology laboratory following standard procedures.

Standard procedures for isolation of pathogens were employed as, potato dextros agar (39 gm of potato dextrose agare with $1000 \mathrm{ml}$ of distilled water) adjusted to $\mathrm{pH}$ 6.5-7.0 and amended with $20 \mathrm{ml}$ (per liter medium) of $5 \%$ streptomycin sulphate (sigma) solution. The solutions were autoclaved at $120{ }^{\circ} \mathrm{C}$ and 121 Pascal for 25 minutes .The autoclaved media were then poured in sterile Petri dishes and solidified. Twigs, leaves and berries from infected plant parts specimen was carefully removed and cut in small sections $(0.5 \times 0.5 \mathrm{~cm})$ excised from the intervening regions of discolored and healthy parts using a sterile scalpel. The sections (4-6 per specimen) was transferred in to plastic petridish having $5 \mathrm{ml}$ of $10 \%$ of sodium hypochlorite (merck), uniformly agitated for one minute and then immediately rinsed in three changes (each change for 1 minutes) of sterile water. After surface disinfecting and blotting, 4 sections per specimen was aseptically plated using sterile forceps in to petridishes $(9 \mathrm{~cm})$ containing potato dextrose agar. The cultures were kept in to incubator adjusted with $21^{\circ} \mathrm{C}$ for 7 days. Growing cultures of each isolate were visually observed with the intention of detecting distinct colony growth, colony color, and growth habit. This was followed by microscopic observation to determine the type of the fungus based on the morphology of its mycelium, fruiting structures, and spores under microscope. Comparisons of morphological characteristics were made using appropriate information sources like web sites and books.

\section{Pathogenecity test}

The conidia used for inoculation was obtained by thoroughly rinsing of the petridish with good colony growth with sterile water in a sterile beaker and stirred up with magnetic stirrer and filtered through double layer cloth. The detached coffee leaves, berries and twigs of ten released coffee varieties were inoculated with a viable conidial suspension using pipettes. All coffee parts were misted with sterile water before inoculation, then after covered with transparent plastic sheet and kept in air conditioned growth room with high relative humidity $(>90 \%)$ and optimum temperature $\left(23-25^{\circ} \mathrm{C}\right)$ for $72 \mathrm{hr}$ to favor infection. The experiments were laid out in completely randomized design (CRD) with three replications. Disease infection and symptom appearance were observed throughout the study period and finally re-isolation was conducted in the laboratory.

Data of diseases reaction on treated coffee plant parts were recorded using scale every five days for six times. 


\section{Results and Discussion}

\section{Symptoms of the disease on infected coffee trees in the field}

The first symptoms of the disease were noticed mainly on the succulent twigs, berries, stems and leaves of the coffee trees. White fungal threads were seen on the young stems and succulents tender tissues of coffee tree. These threads eventually become dark brown in colour. The fungal threads grow and spread to cover underside of leaves (Figure 1).

The disease usually begins on the middle or lower canopies of coffee trees with apparently succulent and actively growing vegetative parts of the plant that spread down the vertical heads with primary or secondary branches leading to complete death. When the rain continues or weather became wet for some time (a week or more), the disease progress at alarming rate and fresh symptoms seen all over the farm, which frustrated growers. However, when the rain stops or became erratic for some time (a week or more), the disease progress also cease and fresh symptoms may not be seen. In such a way, multiple infections are possible per season that finally deteriorated or debilitated the coffee trees although it did not entirely kill the plant unlike vascular wilt or root rot diseases and also it did not affect only coffee berries unlike coffee berry diseases. Such symptoms are similar to that of the disease known as thread blight caused by Corticium koleroga documented so far [5,12-14] officially reported on Arabica coffee as minor and locally important coffee diseases in Ethiopia (Figure 1).

The infected leaves gradually turn dark brown, twigs, and berries followed blackening of nodes that progressed to internodes and darkening of petioles and basal parts of the leaves lamina then the dead leaves were hanging at the same node of infected branches or twigs from strong fungal mycelial threads that can be seen at back side of leaves, berry drop, and dieback of primary branches were seen. Further infection caused by the disease resulted in bare dead stems, dried coffee berries were turning to black brown and die. During the rainy and wet season, most of the infected parts show black rot and white mycelia growth. As the disease develops, these symptoms eventually cover the whole leaves in infected branches. In some cases, as the infected branches and twigs dieback, the axial leaves or tips turn yellow and finally become brownish black. The immature berries at pinhead and expanding stages, mature berries are also very susceptible and become shriveled, blanked and die.

\section{Occurrence and distribution of thread blight of coffee}

The disease syndrome was observed since 1978 at Metu and Gera agricultural research sub-centers, southwestern Ethiopia $[5,12,13]$. However, this disease sporadically occurs between June and September, but increasingly becoming important at high land coffee growing areas around Gera, Metu and "Gumer" Limmu. Thread blight of coffee outbreak was seen for first time in 2008 at Limmu coffee plantation farm of "Gumer" with mean diseases incidence and severity of 49.2 and 9.8, respectively. During the first disease outbreak assessment on four commercial varieties of coffee $(741,74110,75227$ and 744) diseases, severity percent was found to be 14.42, 21.08, 2.48 and 1.17, respectively (Figure 2). The second reported outbreak of the diseases was from Bebeka coffee estate of "Disadis" farm on which 34 hectares of coffee farm was devastated in 2012 (Jimma agricultural research center back to office report, 2012, unpublished). Currently in 2014 number of coffee farms such as Duwina coffee farm of AgriCeft PLC, Limmu coffee Plantation of Horizen PLC and coffee research sub centers such as Gera, Haru, Mugi and Awada reported similar coffee disease symptoms in the same season. At AgriCeft coffee plantation of Duwina farm disease incidence ranged from 5.12 to 92.0 percent per sample plot with average incidence of 50.4 percent and average disease severity of 30.92 percent (Figure 3 ). In the same year, in addition to its prevalence and increased intensity in already affected areas, the disease outbreak was further noted in another coffee growing farm called Limmu Sintu and Gumer with mean incidence and severity of 66.48 and $32.25 \%$, respectively (Figure 4 ). Besides the same symptom was reported from Metu, Gera, Haru, Mugi and Awada Reserch subcenters and experimental sites in South west, West and southern coffee growing areas of the country. According to Girma et. al. [14] thread
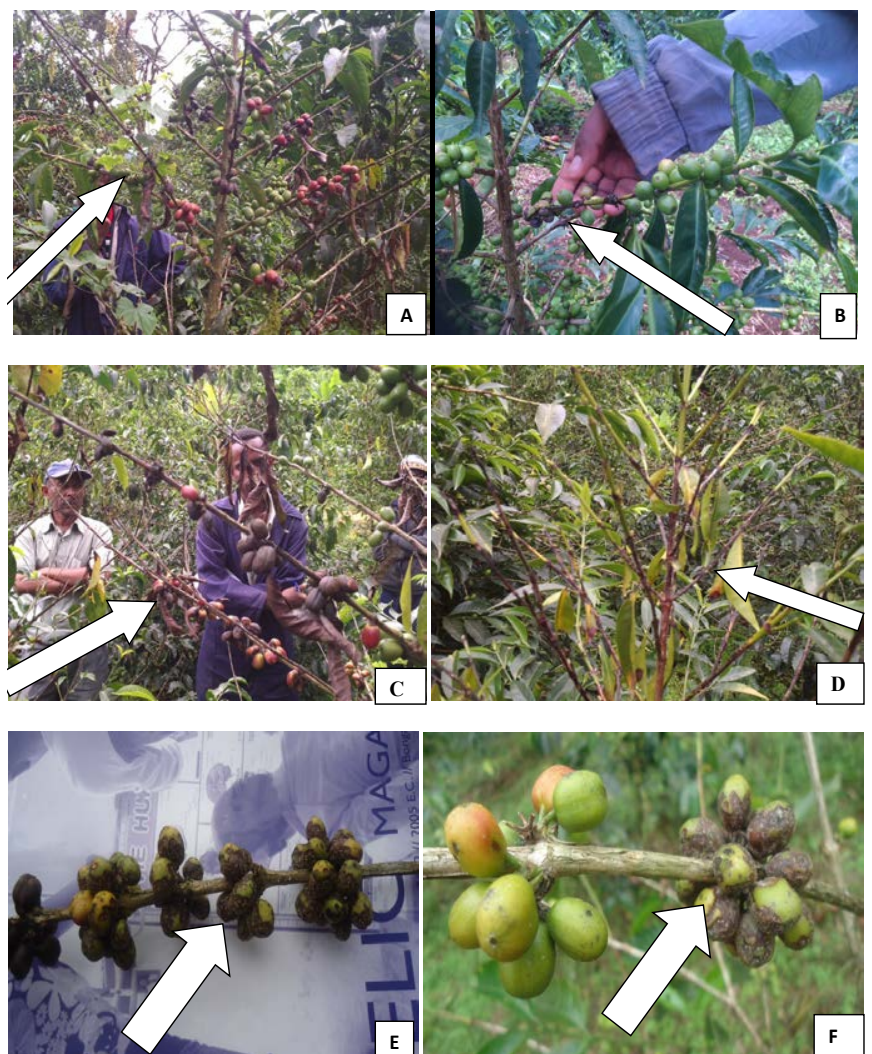

Figure 1: Infected coffee tree branches and stem(A), Infected coffee berries (B), Infected dead leaves were hanging on branches (C); dieback of primary branches $(D)$, black decay and rot of mature berries $(E \& F)$.

Thread blight at Gumer, Limmu Farm, 2008

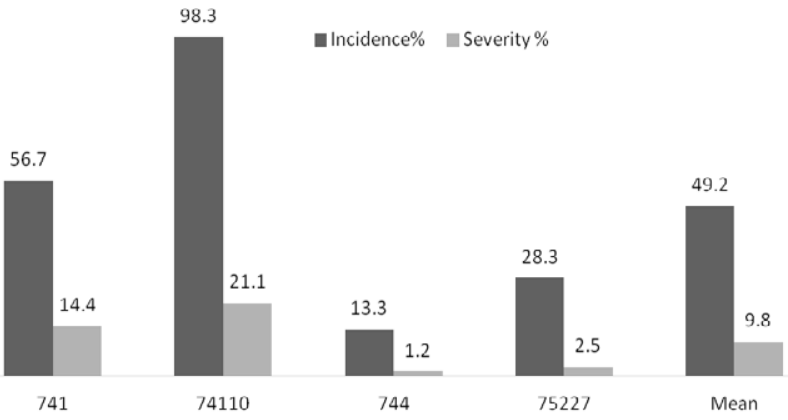

Figure 2: Thread blight percent incidence and severity at Limu Coffee Plantation of Gumer farm, Horizen PLC, in 2008. 


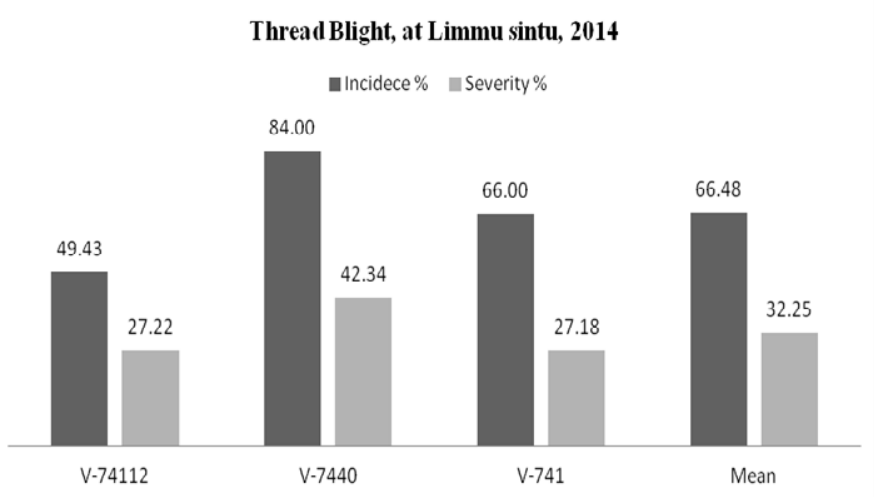

Figure 3: Thread blight percent incidence and severity at Limu Coffee Plantation of Sintu farm, Horizen PLC, 2014 (V stands for variety).

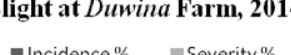

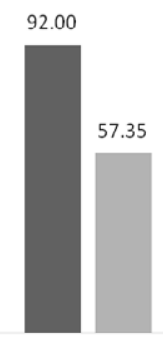

V-74110
Thread Blight at Duwina Farm, 2014

Figure 4: Thread blight percent incidence and severity at Duwina Coffee Plantation, Agriceft Ethiopia, 2014 (V-stands for variety).

blight diseases of coffee was one of locally important coffee diseases in Ethiopia. However, current scenario indicates wider distribution of the disease across geographical areas of coffee growing regions of Ethiopia.

The disease attacked the coffee trees at all stages although there were variations among the trees that perhaps attributed to genetic differences among the coffee types under field conditions where open coffee types affected less than compact ones. It was rather more severe and caused extensive damage on coffee varieties like 741 and 74110 and resulting in complete crop failure. Moreover, the severity was so serious in certain areas with heavy shade and long wet season. This observation indicates that fungal diseases are more sever when atmospheric relative humidity become very high in compact coffee varieties and under heavy shade coffee farms $[16,17]$.

\section{Predisposing factors for the occurrence and outbreaks of} thread blight in Ethiopia

During this study, interviews with most farmers elucidated that they had not experienced such type of disease symptom that rot their coffee and they claimed severe and prolonged wet season for the disease occurrence. Some coffee farm experts also agreed that the occurrence and outbreak of the disease followed the unusual long rainfall with heavy wet season. These observations suggested that such weather calamities might have predisposed the coffee plants to thread blight infections. Matthew (1953) reported similar observations that heavy and continuous rainfall in coffee growing regions of Coorg, Chikmagalur and Hassan districts of Karnataka region of India has triggered berry dropping and fungal disease outbreak of black rot.
The same author reported that outbreaks of thread blight have been reported from Karnataka in previous years with extreme humidity and the name "koleroga" means "rotting disease" and is derived from the Indian Kannada language.

Heavy, long and continuous rainfalls as well as higher relative humidity from the month of june to September has triggered thread blight disease outbreak in 2014 at most coffee growing areas of Ethiopia (Figure 5). Besides other predisposing factors for the occurrence and outbreaks of thread blight are coffee genotypes, heavy shad and build up of diseases causing pathogens made favorable condition. Similarly, development of thread blight was favored by continuous and heavy rainfall, high atmospheric humidity (greater than 80 percent), shade, and overhanging branches. Moreover, the spread of the disease occur by wind, water, insects and other material, as well as mechanical means (Mathew, 1953; Girma et. al. 2009).

\section{Colony morphology of thread blight isolates on culture plates}

The sample infected coffee plant parts were collected from Limmu Sintu, Duina and Gumer coffee farms and from three different locations similar result was obtained. The result of colony morphology of thread blight isolates on culture plates which were collected from different locations was similar in color and growth pattern at early stage. All three days cultures were white in color and profuse fast growth character at obverse and reveres sides. However, pure isolates cultures color slightly changed over time (Figure 6).

\section{Pathogenic reactions of thread blight isolates on detached coffee parts (Leaves, Twigs and Berries) of commercial coffee varieties}

In the pathogenicity test, the thread blight isolates inoculated after sporulation on detached leaves, twigs and berries of different coffee varieties showed symptoms of thread blight disease on most coffee varieties (Figure 7). The symptoms were characteristically related to those observed on infected mature coffee trees where leaves gradually turn dark brown or black decay and rot, twigs and berries are rotted following blackening. There was significant difference among commercial coffee varieties tested for thread blight at Jimma agricultural research center pathology laboratory. The diseases development and severity varies among different coffee varieties and plant parts. Detached leaves, twigs and berry test coffee varieties 74110, 741, 7487, 7440, 754 and 74112, exhibited greater diseases severity which indicates highly susceptible reactions to thread blight under laboratory conditions (Table 1). However, F-59 and F-35 coffee varieties showed lowest diseases severity. From this result it is

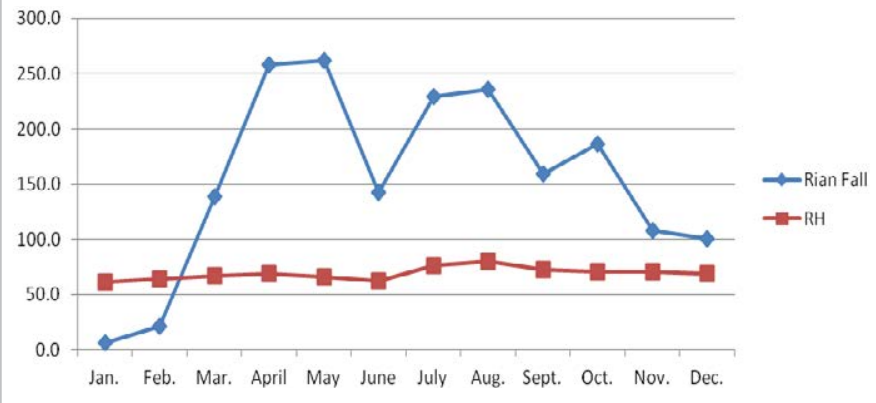

Figure 5: Rain fall and relative humudity measurement of Limmu and its surrounding area in 2014. Source: Jimma Agricultural research center agroMetrology department. 


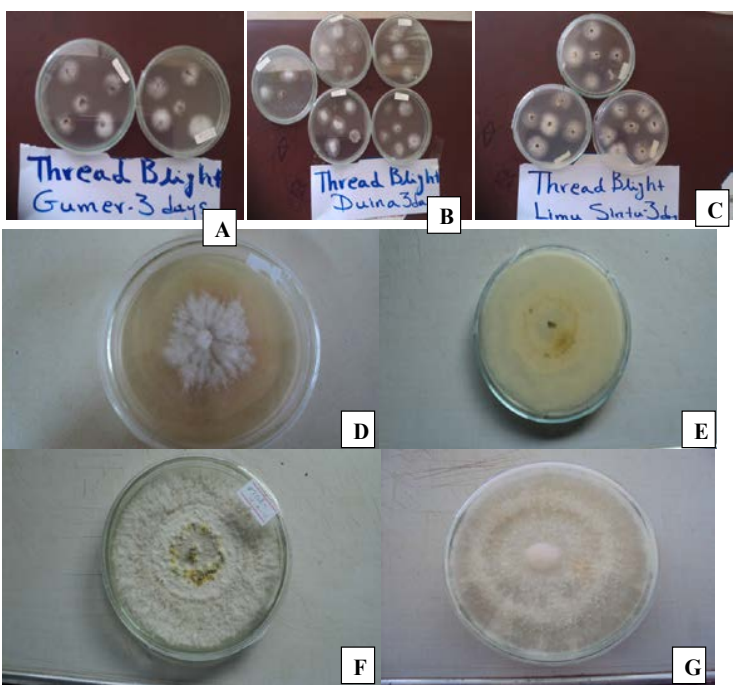

Figure 6: Colony morphology of thread blight isolates on culture plates within three days from three locations $(A, B, C)$ and pure isolates within 10 and 20 days $(D, E, F, G)$.

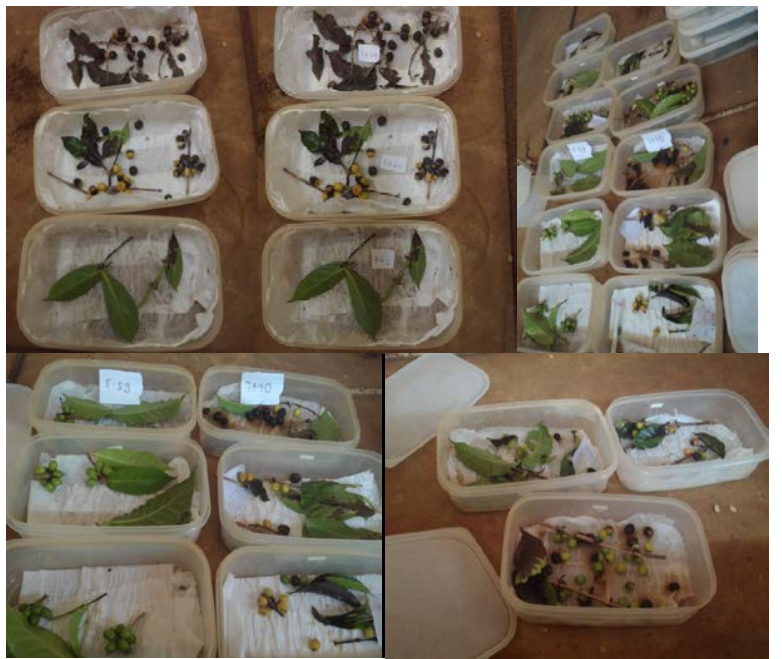

Figure 7: Pathogenic reactions of thread blight isolates on detached coffee parts (Leaves, Twigs and Berries) of different coffee varieties.

\begin{tabular}{|c|c|c|c|}
\hline Treatment & $\begin{array}{c}\text { Leaves } \\
\text { (Disease index }\end{array}$ & $\begin{array}{c}\text { Twigs } \\
\text { (Disease index }\end{array}$ & $\begin{array}{c}\text { Berries } \\
\text { (Disease index }\end{array}$ \\
\hline V- 7487 & +++ & ++ & ++ \\
\hline V-74110 & +++ & +++ & +++ \\
\hline V-7440 & +++ & ++ & +++ \\
\hline V-F-35 & - & ++ & +++ \\
\hline V-74112 & +++ & ++ & ++ \\
\hline V-F-59 & - & - & - \\
\hline V-74140 & ++ & ++ & + \\
\hline V-741 & +++ & +++ & +++ \\
\hline V-754 & +++ & +++ & ++ \\
\hline V-744 & ++ & +++ & +++ \\
\hline
\end{tabular}

Table 1: Pathogenic reactions symptom of thread blight isolates on different coffee varieties on detached coffee parts. ${ }^{\text {ascored }}$ as $-=0 \%$ infection, $+=1-25 \%$ infection, $++=26-50 \%$ infection and $+++=$ greater than $50 \%$ infection. possible to conclude that most of commercial coffee varieties showed susceptible reaction for Corticium koleroga on leaves, twigs and berries when favorable condition for diseases development happened.

Coffee varieties F-59 and F-35 showed tolerant reaction for coffee thread blight (Corticium koleroga). The origin of coffee variety F-59 is southwestern coffee forest at Kaffa zone. It is one of parent coffee verity for hybride coffee variety of "Gawe" which is one of three hybrid coffee varieties developed by Jimma agricultural research center for commercial production. F-35 or "Meoftu" coffee variety is released in 2002 for commercial utilization in Ethiopia. These two coffee varieties showed good hope for farther detailed genetical study against coffee thread blight (Corticium koleroga).

\section{Conclusion}

Thread blight diseases on Ethiopian coffee was known for long time and considered as minor coffee disease. However, it sporadically occurs every five to six years between June and September, but increasingly becoming important and observed in wide coffee growing regions as an epidemic in 2014. The disease epidemics is found to be favored by prolonged rainfall and high relative humidity and prevalence of wet and humid conditions, that perhaps reflects one of the climate change scenarios. The disease has been causing severe damage to Arabica coffee since 2008 in small extent but area wide outbreak was seen in 2014 from August to September thus it may be potential threat to coffee production in future. Thus, further in-depth research on the disease epidemiology and control practices are required along with exploring and developing resistant varieties against the emerging thread blight. While strong efforts have been implemented to contain its large-scale damage to major coffee growing areas in humid west and southwest Ethiopia. Optimization of standard protocol for proper pathogenecity test needs some effort for future screening activity. Moreover, detailed characterization of the thread blight causing organisms or pathogen of Arabica coffee is essential to clear out the present controversies in the pathogen population structure in relation to the disease symptoms.

\section{Acknowledgements}

The Authors acknowledge all staffs of plant pathology research laboratory, Jimma Agricultural Research Center, Ethiopia for their unlimited contribution of the work. We thank Mr. Sisay Tesfaye, Mr. Mamo Abye and Mr. Wondimu Bekele for their technical support throughout the experiment. Special gratitude goes to Ethiopian Institute of Agricultural Research and Jimma Agricultural Research Center for its facilitation for the experiment.

\section{References}

1. ICO (International Coffee Organization) (2012) ICO trade statistics, Exports by exporting countries to all destinations.

2. Osorio N (2002) The Global Coffee Crisis: A Threat to Sustainable Development International Coffee Organization, London.

3. Musoli PC, Girma A, Hakiza GJ, Kangire A, Pinard F, et al. (2009) Breeding for resistance against Coffee Wilt Disease. In Flood J. (ed.). Coffee Wilt Disease. CABI international, UK.

4. ICO (International Coffee Organization) (2013) ICO trade statistics, Exports by exporting countries to all destinations.

5. Derso E, Gebrezigi T, Adugna G (2000) Significance of minor diseases of Coffea arabica L. in Ethiopia: A review. In: Proceedings of the workshop on control of coffee berry disease (CBD) in Ethiopia, Addis Ababa, Ethiopia, pp. 58-65.

6. Kifle B, Demelash T, Gabisa G (2015) Screening of some Coffee arabica Genotypes against Coffee Wilt Diseases (Gibberella xylarioides Heim and Saccus) at Jimma, Southwest Ethiopia. International Journal of Sustainable Agricultural Research 2: 66-76

7. Cavalcante M, Sales F (2001) Ocorrência da queima-do-fio (Pellicularia 
Citation: Belachew K, Teferi D, Hagos L (2015) Coffee Thread Blight (Corticium koleroga): a Coming Threat for Ethiopian Coffee Production. J Plant Pathol Microb 6: 303. doi:10.4172/2157-7471.1000303

koleroga) em cafezais em Rio Branco. Empresa Brasileira de Pesquisa Agropecuaria-Embrapa Acre, Rio Branco.

8. Tims EC, Mills PJ, Exner B (1954) Thread-blight (Pellicularia koleroga) in Louisiana. Journal of Plant Disease 38: 634-637.

9. Ceresini E, Costa S, Marcello Z, Edson F, Nilton L (2012) Evidence that the Ceratobasidium-like white-thread blight and black rot fungal pathogens from persimmon and tea crops in the Brazilian Atlantic Forest agroecosystem are two distinct phylospecies. Genetics and Molecular Biology 35: 480-497

10. Venkatarayan S (1949) The validity of the name Pellicularia koleroga Cooke. Indian Phytopath 2: 186-189.

11. CAB-International (2004) Corticium koleroga (Cooke) Höhn. CAB International Wallingford.

12. Teferi D, Adunga G, Jefuka C, Tesfaye S, Zeru A, et al. (2008) Dynamics of sporadic diseases of coffee in Ethiopia: A review. In: Diversty and knowldage; Proceeding of National Work shop four decads of coffee research and development in Ethiopia, Addis Ababa, Ethiopia, pp. 14-17.
13. Ejeta M (1986) A review of coffee diseases and their control in Ethiopia. In Proceedings of the First Ethiopian Crop Protection Symposium (Tsedeke Abate, ed.) Ethiopian Institute of Agricultural Research, Addis Ababa, Ethiopia pp. 187-195.

14. Adugna G, Jefuka C, Zeru A, Tesfaye A (2009) Advances in Coffee Disease Research in Ethiopia. Abraham Tadesse (ed.) Increasing Crop Production Through Improved Plant Protection-Volume II. Plant Protection Society of Ethiopia (PPSE). PPSE and EIAR, Addis Ababa, Ethiopia, pp. 542.

15. Furtado $E$ (1997) Doenças do chá. In: Kimati H, Amorim L, Bergamim Filho A, Camargo L and Rezende J (eds) Manual de Fitopatologia. 3rd edition. Agronômica Ceres, São Paulo, pp. 257-260.

16. Mathew KT (1953) Studies on Black Rot of Coffee. Doctoral Dissertation. Universty of Madras Botany laboratory, India, Madras.

17. JARC (2014) Jimma Agricultural Research Center Research Progress Report for the Period of 2013/14. Getachew Weldemicheal, Yonas Belete, Worknesh Beker, Kifle Belachew (eds), EIAR/JARC, Jimma, pp: 261. 